\title{
Analisis Karakteristik Iklan Dimas Djay (Budaya Indonesia: Humor dan Kolosal)
}

\author{
Michael Limantara, Gregorius Genep Sukendro \\ michaellimantaral@gmail.com,geneps@fikom.untar.ac.id
}

Fakultas Ilmu Komunikasi Universitas Tarumanagara

\begin{abstract}
Advertising is a part of our modern industrial life. The emergence of new brands in the market faced with much more selective, brand aware consumers has increased the competition amongst the brands. Advertising in a country is an identity that represents the character of the people in that country. But in modern times people's time to pay attention is getting shorter. So this is a challenge for advertisers to create advertisements that attract public attention. One of the advertisers who successfully made interesting advertisements was Dimas Djayadiningrat. Dimas Djay is an advertising director, his works Indoeskrim ad version of "Legenda Nusantara" and Ramayana ad version of "Ramayana Ramadhan" successfully attracted public attention and became viral. The author became interested in knowing more about the figure of Dimas Djay and the characteristics of his advertisements. This study uses a descriptive case study method. In conducting this research the author found the characteristics of Dimas Djay advertising through observation, interviews, and other matters related to this study. From the results of the author's research on the characteristics of the Dimas Djay's advertisement, it has found that three characters are including Indonesian culture, humor, and colossal. It turns out that these three Dimas Djay's ad characters match the Indonesian character. Because Djay makes ads follow the market's wishes, it comes from the taste of the Indonesian people themselves.
\end{abstract}

Keywords: Advertising, culture, humor, colossal

\begin{abstract}
Abstrak
Periklanan pada dasarnya adalah bagian dari kehidupan industri modern. Di zaman modern ini persaingan antar brand semakin sengit dikarenakan ekspansi, munculnya banyak brand baru dan dihadapkan dengan konsumen yang semakin spesifik, selektif, dan fanatik. Iklan di suatu negara merupakan identitas yang merepresentasikan karakter orang-orang di negara tersebut. Tetapi di zaman modern ini, perhatian masyarakat semakin singkat. Hal ini menjadi tantangan bagi pengiklan untuk membuat iklan yang menarik perhatian masyarakat. Salah satu pengiklan yang sukses membuat iklan yang menarik adalah Dimas Djayadiningrat. Dimas Djay adalah sutradara iklan, karya iklanya Indoeskrim versi "Kisah Legenda Nusantara" dan iklan Ramayana versi "Ramayana Ramadhan" sukses menarik perhatian publik dan menjadi viral. Penulis tertarik untuk mengenal lebih jauh sosok Dimas Djay dan karakteristik iklan-iklan hasil produksinya. Penelitian ini menggunakan metode studi kasus. Dalam melakukan penelitian ini penulis menemukan karakteristik iklan Dimas Djay melalui observasi, dan wawancara. Dari hasil penelitian penulis mengenai karakteristik iklan Dimas Djay ditemukan tiga karakter diantaranya budaya Indonesia, humor, dan kolosal. Ketiga karakter iklan Dimas Djay ini sesuai dengan karakter Indonesia karena Djay membuat iklan mengikuti keinginan pasar, berasal dari selera orang Indonesia itu sendiri.
\end{abstract}

Kata Kunci: iklan, budaya, humor, kolosal 


\section{Pendahuluan}

Periklanan pada dasarnya adalah bagian dari kehidupan industri modern. Pada zaman modern ini persaingan antar brand semakin sengit karena ekspansi, munculnya banyak brand baru, dan dihadapkan dengan konsumen yang semakin spesifik, selektif, dan fanatik. Iklan hadir untuk menjembatani kebutuhan brand. Iklan di suatu negara merupakan identitas yang merepresentasikan karakter orang-orang di negara tersebut. Indonesia termasuk negara yang besar dalam permintaan iklan. Tetapi iklan-iklan di Indonesia memiliki format yang tidak jauh berbeda dengan masa sebelumnya. Sebagian besar iklan memperlihatkan produk dari awal hingga akhir. Secara teknis seperti kualitas gambar dan suara terlihat bagus tetapi secara format, konsep, dan pesan yang disampaikan tidak inovatif. Iklan-iklan dengan format ini masih cukup efektif di Indonesia. Tetapi industri periklanan di Indonesia perlu berbenah karena di zaman modern ini perhatian masyarakat semakin singkat. Maka ini menjadi tantangan bagi pengiklan untuk membuat iklan yang berhasil menyita dan menarik perhatian masyarakat.

Dalam satu tahun ini terdapat dua iklan yang menjadi viral bahkan hingga ranah internasional yaitu iklan Indoeskrim versi "Kisah Legenda Nusantara" dan iklan Ramayana versi "Ramayana Ramadhan". Dan sosok dibalik kedua iklan itu adalah Dimas Djayadiningrat atau yang biasa dikenal dengan Dimas Djay, salah satu sutradara terkenal di Indonesia. Dimas Djay mengawali karirnya sebagai sutradara video klip dan film sejak 1996. Pada tahun 2000, Dimas Djay mulai menyutradarai iklan atau pariwara hingga sekarang. Dimas Djay juga pernah menjadi juri di ajang pencarian bakat Indonesia Idol. Selama 18 tahun menekuni bidang periklanan, sudah banyak iklan yang dihasilkan oleh Dimas Djay sehingga namanya diperhitungkan. Dua iklan di atas menjadi viral tanpa menggunakan media mainstream. Penulis tertarik untuk mengenal lebih jauh sosok Dimas Djay. Setelah melihat sejumlah hasil karya Dimas Djay terdapat ciri khas yang tidak dimiliki sutradara pariwara lainnya.

Karakteristik menurut Kamus Besar Bahasa Indonesia adalah mempunyai sifat khas sesuai dengan perwatakan tertentu. Sepanjang karir dalam pembuatan iklan, Dimas Djay sudah bekerja sama dengan banyak klien dan agensi. Walaupun sudah banyak menghasilkan karya iklan, tidak semua iklan bisa dikatakan mempunyai ciri khas yang sama. Hal ini karena keinginan setiap klien dan agensi yang berbeda-beda. Kendati demikian, selalu ada ciri khas dan konsistensi karya iklan Dimas Djay yang dibuat sejak awal tahun 2000. Dengan demikian karakteristik dapat dikatakan sesuatu yang memiliki sifat, ciri khas tertentu, identitas yang berlangsung secara konsisten.

Unsur karakteristik yang terdapat dalam iklan Dimas Djay diantaranya adalah: Pertama, humor. Unsur paling khas dari Dimas Djay. Humor dalam karya iklan Dimas Djay memiliki ciri khas tersendiri, berbeda dengan humor-humor lainnya. Kedua, budaya Indonesia. Unsur budaya Indonesia dipastikan ada di semua iklan Dimas Djay tanpa terkecuali, karena Dimas Djay ingin menunjukan iklan buatan Indonesia. Dalam beberapa iklannya juga terdapat unsur budaya lokal, sesuatu yang asli berasal dari kebudayaan keseharian masyarakat Indonesia. Ketiga, kolosal. Dalam arti, dibuat secara besar-besaran. Unsur ini menarik karena banyak orang tidak mengetahui arti sebenarnya dari kolosal.

Penulis memilih tiga iklan yang menggambarkan masing-masing unsur karakteristik iklan Dimas Djay, tetapi tidak menutup kemungkinan iklan yang dipilih juga terdapat unsur karakteristik lainnya. Iklan yang dipilih menggambarkan unsur humor adalah iklan Indoeskrim versi "Kisah Legenda Nusantara". Iklan yang dipilih 
menggambarkan unsur Budaya Indonesia adalah iklan Ramayana versi "Ramayana Ramadhan". Iklan untuk unsur kolosal adalah iklan Diplomat Mild versi "Fotografer". Penulis ingin menemukan unsur-unsur karakteristik iklan Dimas Djay dalam 3 iklan tersebut.

Dengan demikian, penulis merumuskan permasalahan penelitian yakni apa karakteristik iklan-iklan Dimas Djay? apa saja unsur humor dalam iklan Dimas Djay? Unsur-unsur kebudayaan Indonesia dan budaya lokal apa yang ada dalam iklan Dimas Djay? serta apa arti dan unsur kolosal yang terdapat dalam iklan Dimas Djay?

\section{Metode Penelitian}

Jenis penelitian yang penulis gunakan adalah penelitian kualitatif. Deniz dan Lincoln (dalam Moleong, 2009) menyatakan bahwa penelitian kualitatif adalah penelitian yang menggunakan latar alamiah, dengan maksud menafsirkan fenomena yang terjadi dan dilakukan dengan jalan melibatkan berbagai metode yang ada. Metode yang biasanya dimanfaatkan adalah wawancara, pengamatan, dan pemanfaatan dokumen. Strategi penelitian yang digunakan dalam penelitian ini menggunakan metode deskriptif studi kasus. Metode penelitian deskriptif adalah suatu metode dalam meneliti status sekelompok manusia, suatu objek, suatu set kondisi, suatu sistem pemikiran, ataupun suatu kelas peristiwa pada masa sekarang (Nazir 2011). Apabila peneliti berorientasi pada kehendak memahami karakteristik individu maupun kelompok tertentu secara mendalam penelitian lapangan yang dilakukan termasuk studi kasus (Basrowi dan Suwandi 2008).

Subjek dalam penelitian ini adalah Dimas Djay dan objeknya adalah iklan-iklan Dimas Djay. Dalam penelitian ini, peneliti menggunakan beberapa metode pengumpulan data agar dapat mengumpulkan data dan juga informasi yang lebih dalam dengan berbagai cara, yaitu wawancara, observasi, studi kepustakaan, dan penelusuran data online. Teknik analisa data yang digunakan pada penelitian ini adalah tenik analisis data kualitatif Miler dan Huberman. Menurut Miler dan Huberman (1992) dalam Gunawan (2014) terdapat tiga teknik analisis data yaitu reduksi data, penyajian data, dan kesimpulan atau verifikasi. Salah satu cara paling penting dan mudah dalam uji keabsahan hasil penelitian adalah dengan melakukan triangulasi. Triangulasi adalah teknik pemerikasaan keabsahan data dengan memanfaatkan yang lain di luar data yang sudah ada untuk keperluan mengecek kembali atau sebagai pembanding terhadap data yang sudah ada tersebut (Moelong, 2012). Dalam penelitian ini penulis menggunakan 2 langkah pengujian keabsahan, yaitu triangulasi dengan sumber data dan triangulasi dengan metode.

\section{Hasil Temuan dan Diskusi}

Dalam penelitian ini penulis menemukan tiga karakter iklan Dimas Djay yaitu Budaya Indonesia, humor, dan kolosal yang akan dijabarkan sebagai berikut:

Budaya Indonesia

Karakter Budaya Indonesia terdapat dalam iklan-iklan Dimas Djay. Penulis memilih iklan Ramayana versi "Ramayana Ramadhan" sebagai bahan penelitian untuk menggambarkan Budaya Indonesia. Menurut Kurniawan (2012:1), budaya adalah suatu cara hidup yang berkembang dan dimiliki bersama oleh sebuah kelompok orang dan diwariskan dari generasi ke generasi. Budaya terbentuk dari banyak unsur yang 
rumit, termasuk sistem agama dan politik, adat istiadat, bahasa, perkakas, pakaian, bangunan, dan karya seni. Kebudayaan sangat erat hubungannya dengan masyarakat. Budaya memiliki beberapa elemen atau komponen, menurut ahli antropologi Cateora dalam Kurniawan (2012), yaitu:

- Kebudayaan Material

Kebudayaan material mengacu pada semua ciptaan masyarakat yang nyata, konkret. Termasuk dalam kebudayaan material ini adalah temuantemuan yang dihasilkan dari suatu penggalian arkeologi: mangkuk tanah liat, perhiasan, senjata, dan seterusnya. Kebudayaan material juga mencakup barang-barang, seperti televisi, pesawat terbang, stadion olahraga, pakaian, gedung pencakar langit, dan mesin cuci. Dimas Djay sendiri selalu ingin ada unsur yang menrepresentasikan identitas Indonesia di dalam karya-karyanya sekecil apapun itu. Dalam iklan ini terlihat properti dan barang-barang yang diapakai merepresentasikan Indonesia diantaranya adalah: uang, pakaian, dan lingkungan sekitar

- Bahasa

Bahasa merupakan alat pengantar dalam berkomunikasi. Bahasa untuk setiap wilayah, bagian dan negara memiliki perbedaan yang sangat komplek. Dalam ilmu komunikasi, bahasa merupakan komponen komunikasi yang sulit dipahami. Bahasa memiliki sifat unik dan komplek, yang hanya dapat dimengerti oleh pengguna bahasa tersebut. Jadi keunikan dan kompleksitas bahasa ini harus dipelajari dan dipahami agar komunikasi lebih baik dan efektif dengan memperoleh nilai empati dan simpati dari orang lain. Bahasa tentunya terdapat dalam iklan-iklan Dimas Djay karena sejatinya proses pembuatan iklan di Indonesia dan ditujukan untuk pasar Indonesia. Bahasa merupakan identitas yang kuat dan jelas dalam menggambarkan kebudayaan. Bahasa yang digunakan dalam iklan ini adalah Bahasa Indonesia, mulai dari lirik lagu, Voice Over (VO), hingga percakapan.

- Sistem Kepercayaan

Bagaimana masyarakat mengembangkan dan membangun sistem kepercayaan atau keyakinan terhadap sesuatu. Hal ini akan mempengaruhi sistem penilaian yang ada dalam masyarakat. Sistem keyakinan ini akan mempengaruhi dalam kebiasaan, bagaimana memandang hidup dan kehidupan, cara mereka berkonsumsi, sampai dengan cara bagaimana berkomunikasi. Iklan Ramayana ini bertemakan Ramadhan. Sudah menjadi tradisi di Indonesia sejak dahulu untuk mudik ketika Lebaran. Lebaran adalah hari raya umat Islam yang dirayakan setiap tahun setelah melaksanakan puasa di bulan Ramadan. Umat Muslim terutama pekerja yang merantau kembali ke kampung halaman mereka untuk bersilahturami dan merayakan lebaran dengan orang tua dan sanak saudara.

- Kebudayaan Nonmateril

Kebudayaan nonmaterial adalah ciptaan-ciptaan abstrak yang diwariskan dari generasi ke generasi, misalnya berupa dongeng, cerita rakyat, dan lagu atau tarian tradisional. Qasidah di iklan Ramayana ini khususnya di Indonesia mengalami banyak akulturasi dengan budaya negara asalnya. Qasidah adalah lagu yang mengandung unsur dakwah sesuai ajaran Islam. Lagu ini biasanya dibawakan oleh delapan orang yang dinyanyikan dengan gembira. Di Indonesia Qasidah ini sudah ada sejak ajaran Islam ke Indonesia dan di ubah liriknya menggunakan Bahasa Indonesia. Qasidah modern seperti 
di Indonesia sudah mengalami banyak perubahan seperti tidak hanya menggunakan rebana, tapi menggunakan alat-alat musik modern yang lain seperti gitar misalnya. Qasidah dalam iklan Ramayana ini masuk ke dalam Kebudayaan Nonmateril.

Budaya lokal juga kerap kali ada di dalam iklan-iklan Dimas Djay seperti pada iklan Ramayana ini. Unsur lokal merupakan karakter yang khas dalam iklan Dimas Djay. Kearifan lokal menurut Sedyawati (2006) adalah kearifan dalam kebudayaan tradiosonal, dengan catatan bahwa yang dimaksud dalam hal ini adalah kebudayaan tradisional suku-suku bangsa. Kata "kearifan" sendiri hendaknya juga dimengerti dalam arti luasnya, yaitu tidak hanya berupa norma-norma dan nilai-nilai budaya, melainkan juga segala unsur gagasan, termasuk yang berimplikasi pada teknologi, penanganan kesehatan, dan estetika. Dapat disumpulkan kearifan lokal adalah budaya asli dari daerah tersebut. Dalam ikan-iklan Dimas Djay terlihat unsur lokal yang sangat kental. Lokal yang dimaksud Djay adalah budaya kita, budaya asli setempat kita, budaya yang kita mengerti, budaya yang berasal dari keseharian kita sendiri. Djay selalu bisa menemukan insight dalam budaya lokal Indonesia dan menuangkannya ke dalam karya-karyanya. Budaya lokal yang terdapat di iklan ini diantaranya: merantau, dipalak preman, pakaian baru, dan membawa buah tangan.

\section{Humor}

Humor merupakan karakter yang tidak bisa dipisahkan dari iklan Dimas Djay. Humor menurut Kamus Besar Bahasa Indonesia (KBBI) adalah sesuatu yang lucu: mempunyai rasa; keadaan (dalam cerita dan sebagainya) yang menggelikan hati; kejenakaan; kelucuan. Menurut Shimp (2014) Iklan humor atau lucu umumnya melibatkan penggunaan resolusi keganjilan. Keganjilan terjadi ketika makna dari sebuah iklan tidak secara jelas. Bingung dengan keganjilan, konsumen diprovokasi untuk memahami makna iklan dan menyelesaikan keganjilan. Ketika makna tersebut akhirnya ditentukan (misalnya, ketika humor dalam iklan terdeteksi) perasaan kejutan yang dialami, dan itu adalah sensasi kejutan yang menghasilakn respon lucu. Pada gilirannya, respon lucu ini dapat menimbulkan sikap yang menguntungkan terhadap iklan dan mungkin terhadap merek yang diiklankan itu. Humor adalah sesuatu yang lucu, jenaka dari suatu hal yang menggelikan atau ganjil. Iklan humor umumnya memiliki unsur keganjilan, ganjil di sini mempunyai arti sesuatu yang terjadi tidak semestinya, sesuatu yang tidak seperti biasanya. Humor sangat efektif untuk menarik perhatian konsumen, tidak heran jika para pengiklan sering memasukan unsur humor dalam iklannya. Begitupun dengan iklan-iklan Dimas Djay yang banyak mengandung unsur humor. Pada pembahasan ini iklan yang dipilih mewakili unsur humor adalah iklan Indoeskrim versi "Kisah Legenda Nusantara". Unsur humor yang terdapat dalam iklan ini seperti penggunaan alat modern seperti smartphone dan handy talky (HT) yang semestinya tidak ada pada masa itu. Humor lainnya ada pada karakter talent yang unik seperti tertawa berlebihan atau bergumam dalam hati ala-ala sinetron Indonesia. Hal ini adalah hal-hal yang tidak masuk akal, pengecohan dari sesuatu yang biasa sehingga menyebabkan kejutan yang menyenangkan.

\section{Kolosal}

Menurut KBBI kolosal adalah (dibuat dan sebagainya) secara besar-besaran; luar biasa besaranya. Misalnya proses pembuatan film kolosal ini dibuat dengan melibatkan banyak orang. Umunya kolosal dapat ditemui pada film-film atau serial 
drama yang bertemakan kerajaan atau peperangan, contoh film gladiator (2000) dan Film 300 (2006). Tetapi kolosal tidak hanya sesuatu yang berbau tentang peperangan kerajaan di masa lalu, film-film di masa sekarang seperti Avengers: Infinity War (2018) juga termasuk kolosal, karena proses pembuatannya melibatkan banyak orang. Kolosal tidak hanya sebatas film saja, video klip, iklan, atau bahkan membangun sebuah proyek gedung atau sebagainya juga dapat dikatakan kolosal. Menurut Dimas Djay, kolosal tidak harus banyak orang, tetapi lebih kepada rasa. Pada umumnya, set up kolosal melibatkan orang banyak tetapi ada banyak cara untuk membuat kolosal. Pada penelitian ini penulis memilih iklan Diplomat Mild versi "Fotografer" untuk mewakili karakter kolosal.

Dimas Djay menjelaskan banyak hal tentang kolosal termasuk elemen-elemen atau unsur yang ada untuk memberikan rasa pada karya tersebut. Unsur-unsur itu diantaranya konten/tema, visual, kata-kata, dan musik. Di iklan ini juga terdapat unsurunsur tersebut di antaranya.

- Konsep

Tema dari iklan ini adalah fotografer perang, di mana tema yang diusung adalah tema yang dalam dan kuat karena tentang foto jurnalistik. Foto memiliki kekuatan sendiri dibanding media lainnya terutama foto jurnalistik, foto yang bercerita. Foto dapat menggambarkan emosi dan suasana yang terjadi, ketika media lain tidak bisa menggambarkannya. Tema disini lah yang menjadi pondasi kuat untuk memberikan rasa tersebut.

- Visual

Visual yang ditampilkan dalam iklan ini terlihat massa dan aparat, kerusuhan, medan yang sulit untuk jurnalis. Visual yang ditampilkan memberikan rasa yang mencekam. Tidak hanya itu dalam iklan ini juga diperlihatkan sang fotografer walau sudah terjatuh tetapi tetap bangkit dan tidak menyerah pada pilihannya. Dengan visual yang baik dapat mendukung unsur-unsur lainnya unuk membuat sesuatu yang besar.

- Kata-kata

Kata-kata merupakan peran penting untuk membuat rasa itu. Kata-kata yang di buat di iklan ini memiliki makna perjuangan yang kuat. Kata-kata dalam iklan ini dapat menyentuh perasaan yang menonton yang bisa menciptakan perasaan besar itu.

- Musik

Musik juga menjadi faktor yang mendukung unsur-unsur lainnya, di iklan musik yang dipilih sesuai dengan konsep utama.

Kolosal menurut Dimas Djay tidak harus melibatkan banyak orang, tetapi lebih pada rasa. Ketika penonton tersentuh hatinya, hal itu bisa merupakan rasa dari iklan. Iklan-iklan kolosal Dimas Djay memiliki banyak genre salahsatunya genre corporate yang digarap dengan konsep serius dan dalam. Ada juga iklan dengan konsep storryteling dengan durasi panjang dan melibatkan unsur emosi di dalamnya.

\section{Simpulan}

Dari hasil penelitian penulis mengenai karakteristik iklan Dimas Djay ditemukan tiga karakter diantaranya budaya Indonesia, humor, dan kolosal. Ketiga karakter iklan Dimas Djay ini sesuai dengan karakter Indonesia. Hal ini karena Djay membuat iklan mengikuti keinginan pasar, berasal dari selera orang Indonesia itu sendiri. Ketiga 
karakater ini sebenarnya sangat berhubungan antara satu dengan yang lainnya yang dapat terlihat dari keseharian orang Indonesia. Tiga karakter ini menggambarkan Indonesia yang besar banyak budaya, suku, bahasa, dan orang Indonesia yang senang dengan guyonan-guyonan.

\section{Ucapan Terima Kasih}

Ucapan terima kasih penulis berikan kepada Dimas Djayadiningrat dan Danny Masli yang telah meluangkan waktu selaku narasumber. Penulis juga ingin mengucapkan terima kasih kepada dosen pembimbing Genep Sukendro serta Fakultas Ilmu Komunikasi Universitas Tarumanagara.

\section{Daftar Pustaka}

Basrowi., \& Suwandi. (2008). Memahami Penelitian Kualitatif. Jakarta: Rineka Cipta. Bungin, Burhan. (2010). Penelitian Kualitatif: Komunikasi, Ekonomi Kebijakan Publik, dan Ilmu Sosial Lainnya. Jakarta: Kencana Prenada Media Group.

Gunawan, Imam (2014). Metode Penelitian Kualitatif Teori dan Praktik. Jakarta: PT Bumi Aksara.

Kamus Besar Bahasa Indonesia Pusat Bahasa, Edisi Keempat. (2008). Jakarta: Gramedia Pustaka Utama.

Kurniawan, Benny. (2012). Ilmu Budaya Dasar. Tangerang: Jelajah Nusa.

Moelong, Lexy J. (2012). Metedologi Penelitian Kualitatif. Bandung: PT. Remaja Rosdakarya.

Moleong, Lexy J. (2009). Metodologi Penelitian Kualitatif. Bandung: PT Remaja Rosdakarya.

Nazir, Moh. (2011). Metode Penelitian. Bogor: Ghalia Indonesia.

Sedyawati. Edi. (2006). Budaya Indonesia: Kajian Arkeologi, Seni, dan Sejarah. Jakarta: PT Raja Grafindo Persada.

Shimp, Terence A. (2014). Komunikasi Pemasaran Terpadu dalam Periklanan dan Promosi. Jakarta: Salemba Empat. 